\title{
KEMAMPUAN PROFESIONAL GURU BIOLOGI \\ DALAM MEMAHAMI DAN MERANCANG MODEL PEMBELAJARAN KONSERVASI BIODIVERSITAS DI SMA
}

\author{
Suroso Mukti Leksono ${ }^{1,2}$, Nuryani Rustaman ${ }^{1}$, dan Sri Redjeki ${ }^{1}$ \\ ${ }^{1}$ Sekolah Pascasarjana Universitas Pendidikan Indonesia \\ ${ }^{2}$ FKIP Universitas Sultan Ageng Tirtayasa \\ email: sumule56@yahoo.com
}

\begin{abstract}
Abstrak: Tujuan penelitian ini adalah untuk mengetahui penguasaan konsep konservasi biodiversitas guru biologi dan cara mengajarkannya. Penelitian ini menggunakan metode deskriptif dengan menggunakan angket pada 31 guru SMA/MA di Kota/Kab Serang. Hasil penelitian menunjukkan bahwa 52\% guru telah memahami konsep biodiversitas, namun hanya 3\% yang memahami konsep konservasi. Model yang digunakan guru dalam mengajarkan konservasi biodiversitas, 58\% menggunakan observasi, $45 \%$ diskusi, $23 \%$ ceramah dan 16\% tanya jawab. Untuk tingkat kesukaran, $87 \%$ guru beranggapan mudah memahami materi konservasi biodiversitas dan $81 \%$ beranggapan mudah mengajarkannya dibandingkan dengan materi IPA lainnya. Guru-guru selama ini hanya 6\% saja yang memperoleh pengetahuan tentang konservasi biodiversitas pada saat pelatihan. Oleh sebab itu diperlukan pelatihan-pelatihan melalui Continuing Professional Development (CPD).
\end{abstract}

Kata Kunci: guru profesional, konservasi biodiversitas, continuing professional development (CPD)

\section{BIOLOGY TEACHERS' PROFESSIONAL ABILITY IN UNDERSTANDING AND DESIGNING INSTRUCTION ON BIODIVERSITY CONSERVATION IN SMA}

\begin{abstract}
The purpose of this study was to gain the knowledge about biology teachers' concept mastery on biodiversity conservation as well as how to teach it. This study used descriptive methods with the questionnaires to 31 respondents of SMA/MA in Kota/KabSerang. The research result showed that $52 \%$ respondents had mastered the biodiversity concept. However, only $3 \%$ of respondents had fully mastered biodiversity conservation. In addition, for the teaching methods $58 \%$ respondents used observation, $45 \%$ respondents used discussion, $23 \%$ respondents used lecturing and $16 \%$ respondents used an interactive method. Moreover, for the difficulty level, $87 \%$ of respondents argued that it was easy to master the biodiversity conservation materials and $81 \%$ said that it was easier to teach the concept than other concepts. Only $6 \%$ of the teachers had gained the knowledge about biodiversity conservation when they had the training. Thus, the training is urgently needed to train the teachers in order to guarantee the Continuing Professional Development (CPD).
\end{abstract}

\section{Keywords : teacher professional, biodiversity conservation, continuing professional development (CPD)}

\section{PENDAHULUAN}

Indonesia merupakan salah satu negara megabiodiversitas karena memunyai kekayaan keanekaragaman hayati yang tinggi di dunia. Walaupun luasnya hanya $1,3 \%$ dari luas total daratan dunia, Indonesia memiliki sedikitnya 90 tipe ekosistem, mulai dari padang salju di puncak Jaya Wijaya, sub alpin, pegunungan hingga hutan dataran rendah, hutan pantai, padang rumput, savana, lahan basah, muara dan pesisir pantai, mangrove, padang lamun, terumbu karang hingga perairan laut dalam. Dalam hal kekayaan spesies di Indonesia terdapat sekitar 12\% (515 spesies, 39 endemik) dari total spesies mamalia, 7,3\% (511 spesies, 150 endemik) dari total spesies reptil di dunia, sekitar $17 \%$ (1531 spesies, 397 endemik) dari total spesies burung di dunia, 270 spesies amfibi (100 endemik), dan 2.827 spesies binatang tidak bertulang belakang, selain ikan air tawar (Indrawan 
dkk, 2007:456). Namun, sebagian besar masyarakat Indonesia tidak menyadarinya. Salah satu contoh nyata adalah buku-buku pelajaran di sekolah sering kali menggunakan contoh-contoh hewan dari mancanegara, seperti burung unta, beruang kutub, dan jerapah. Hanya sebagian kecil saja yang menggunakan contoh-contoh makhluk hidup dari lingkungan di sekitarnya. Hal ini diduga menjadi salah satu penyebab tidak pedulinya masyarakat akan pentingnya manfaat keanekaragaman hayati di sekitarnya.

Pembelajaran konservasi biodiversitas pada saat ini di Indonesia telah tercantum dalam kurikulum SMA/MA. Pada Kurikulum yang saat ini berlaku, yaitu Kurikulum Tingkat Satuan Pendidikan (KTSP) untuk jenjang SMA/ MA, pembelajaran biodiversitas dan konservasinya tercantum pada Standar Kompetensi nomor 3, yaitu memahami manfaat keanekaragaman hayati, dengan Kompetensi Dasar 3.1. mendeskripsikan konsep keanekaragaman gen, jenis, dan ekosistem melalui kegiatan pengamatan; dan 3.2. mengomunikasikan keanekaragaman hayati Indonesia dan usaha pelestarian serta pemanfaatan sumber daya alam. Untuk dapat mencapai kompetensi standar tersebut diperlukan guru-guru yang profesional dalam membelajarkan konservasi biodiversitas sehingga pada akhirnya kesadaran tentang konservasi di Indonesia akan terwujud.

Guru yang profesional menurut Undangundang RI No. 14 tahun 2005 tentang guru dan dosen adalah guru yang mempunyai empat kompetensi dasar, yaitu kompetensi profesional, kompetensi pedagogi, kompetensi sosial dan kompetensi kepribadian. Kompetensi profesional merupakan kompetensi yang berkaitan dengan kemampuan guru dalam menguasai materi yang berkaitan bidangnya, dalam hal ini adalah konsep konservasi biodiversitas. Kompetensi pedagogi menekankan penguasaan kompetensi dalam cara mengajar (how to teach). Dalam hal ini kemampuan mengajarkan konservasi biodiversitas sesuai dengan kompetensi dasar yang diharapkan dalam kurikulum. Kompetensi sosial berkaitan dengan kompetensi guru dalam kehidupan sosial. Kemampuan kepribadian juga penting karena guru sebagai pendidik dan pengajar. Berdasarkan latar belakang tersebut, tujuan penelitian ini adalah ingin mengetahui kemampuan profesional guru biologi dalam memahami dan merancang model pembelajaran konservasi biodiversitas di SMA di Kabupaten/Kota Serang, Provinsi Banten.

\section{METODE}

Penelitian ini menggunakan metode deskripstif, yaitu ingin mengambarkan kemampuan profesional guru biologi dalam memahami konsep konservasi biodiversitas dan kemampuannya dalam merancang pembelajaran konservasi biodiversitas untuk SMA. Penelitian ini dilaksanakan pada Bulan Februari 2012 sampai dengan Mei 2012. Pengambilan data menggunakan teknik sampling dengan menyebarkan angket pada responden yang dipilih secara acak pada guru biologi di SMA/MA di Kota/Kabupaten Serang. Responden dalam penelitian ini sebanyak 31 guru SMA/MA yang berasal dari 24 sekolah yang mengajar di kelas 1 SMA di Kota/Kabupaten Serang, dengan asumsi bahwa konsep konservasi biodiversitas pada kurikulum KTSP diajarkan pada kelas 1 semester 2. Sekolah yang menjadi sampel penelitian adalah 3 MA Swasta, 2 MA Negeri, 7 SMA Swasta dan 12 SMA Negeri di Kota/Kabupaten Serang, Banten.

Instrumen yang digunakan untuk mengetahui kemampuan profesional guru biologi dalam memahami konsep konservasi biodiversitas adalah angket terbuka dan tertutup. Angket terbuka berisi pertanyaan-pertanyaan tentang pemahaman konsep konservasi biodiversitas, cara mengajarkannya dan pengembangan pembelajaran konservasi biodiversitas di SMA. Angket tertutup bertujuan untuk mengetahui sumber informasi guru dalam mendapatkan konsep konservasi biodiversitas, dan seberapa sukar memahami serta mengajarkan materi tersebut. Selain itu, angket tertutup juga berisi tentang pengembangan profesional guru dalam mendapatkan pelatihan tentang filosofi, teknik mengajar, asesmen dan permasalahan global serta lokal yang terkait dengan konservasi biodiversitas. Penilaian Rencana Pelaksanaan Pembelajaran (RPP) yang dibuat guru dalam mengajar- 
kan konsep konservasi biodiversitas adalah untuk mengetahui kemampuan guru biologi dalam merencanakan model pembelajaran konservasi biodiversitas.

\section{HASIL DAN PEMBAHASAN}

\section{Pemahaman Guru Biologi Tentang Konsep Konservasi Biodiversitas}

Biodiversitas atau yang dikenal dengan keanekaragaman hayati adalah kekayaan hidup di bumi, jutaan tumbuhan, hewan dan mikroorganisme, genetik yang dikandungnya dan ekosistem yang dibangun menjadi lingkungan hidup. Keanekaragaman hayati dapat dilihat dari tiga tingkatan, yaitu tingkat genetik, spesies, dan ekosistem (Maclaurin dan Sterelny, 2008:2). Keanekaragaman genetik berhubungan dengan variasi genetik dalam satu spesies, baik di antara populasi-populasi yang terpisah secara geografis maupun di antara individu-individu dalam satu populasi. Keanekaragaman spesies berhubungan dengan semua spesies di bumi, mulai dari kingdom eubacteria, archabacteria, protista, fungi, tumbuhan sampai kingdom hewan. Keanekaragaman ekosistem berhubungan dengan komunitas biologi yang berbeda-beda serta asosiasinya dengan lingkungan fisik. (Campbell dkk, 2008:1246).

Pemahaman guru biologi di Kabupaten/ Kota Serang terhadap konsep biodiversitas dapat dilihat pada Gambar 1. Terlihat bahwa Guru Biologi di Kabupaten/Kota Serang, 52\% telah memahami konsep biodiversitas secara holistik. Artinya bahwa mereka telah memahami biodiversitas dari tingkat genetik, spesies dan ekosistem. Pada Gambar 1 juga terlihat bahwa, 42\% guru biologi di Kabupaten/Kota serang belum memahami konsep biodiversitas secara holistik atau memahami sebagian saja, dan bahkan $6 \%$ guru tidak memahami konsep biodiversitas.

Guru yang pemahaman konsep biodiversitasnya tidak holistik, sebagian besar $(84,62 \%)$ menyamakan konsep biodiversitas sama dengan keanekaragaman spesies, 7,69\% menyamakan dengan keanekaragaman ekosistem, dan tidak ada $(0 \%)$ yang menyamakan dengan keanekaragaman genetik. Mereka juga sebagian kecil (7,69\%) menyamakan biodiversitas dengan kombinasi keanekaragaman spesies dan ekosistem, namun tidak ada $(0 \%)$ yang menyamakan konsep biodiversitas dengan kombinasi genetikspesies maupun genetik-ekosistem. Hal ini dapat ditarik kesimpulan bahwa konsep biodiversitas dipahami sebagian guru sebagai keanekaragaman sepesies saja, yang seharusnya mencakup tiga tingkatan, yaitu genetik, spesies dan ekosistem. Temuan ini juga sejalan dengan penelitian Lude (2010:23) di University of Kassel di German, yang menyatakan bahwa 64\% calon guru di German hanya memahami sebagian konsep biodiveritas dan $80 \%$ nya menyatakan bahwa biodiversitas indentik dengan keanekaragaman jenis.

Pemahaman biodiversitas yang belum holistik ini salah satu penyebabnya adalah sistem pembelajaran konservasi biodiversitas di Indonesia yang belum sesuai. Hagenbuch $d k k$ (2009) mengemukakan bahwa untuk meningkatkan pemahaman konservasi biodiversitas, sistem pembelajaran dan evaluasinya mencakup multi-component yang meliputi konsep, sikap dan proses. Leksono dan Rustaman (2012) mengemukakan bahwa pembelajaran konservasi biodiversitas di Indonesia masih menekankan pada penguasaan konsep saja belum mencakup ketiga komponen tersebut.

Pemahaman guru biologi tentang makna konservasi dapat dilihat pada Gambar 2. Berdasarkan Gambar 2, terlihat bahwa hanya sebagian kecil (3\%) guru biologi di Kab./Kota Serang yang memahami makna konservasi secara holistik. Makna konservasi secara holistik menurut Western \& Pearl (1989:31) mencakup tiga prinsip, yaitu pendekatan save, study dan use atau perlindungan, peneilitan dan pemanfaatan. Menurut Supriatna (2004) tiga prinsip tersebut bersifat holistik, yaitu pendekatan menyeluruh yang diharapkan dapat melindungi spesies dengan tidak meninggalkan aspek manfaat. 


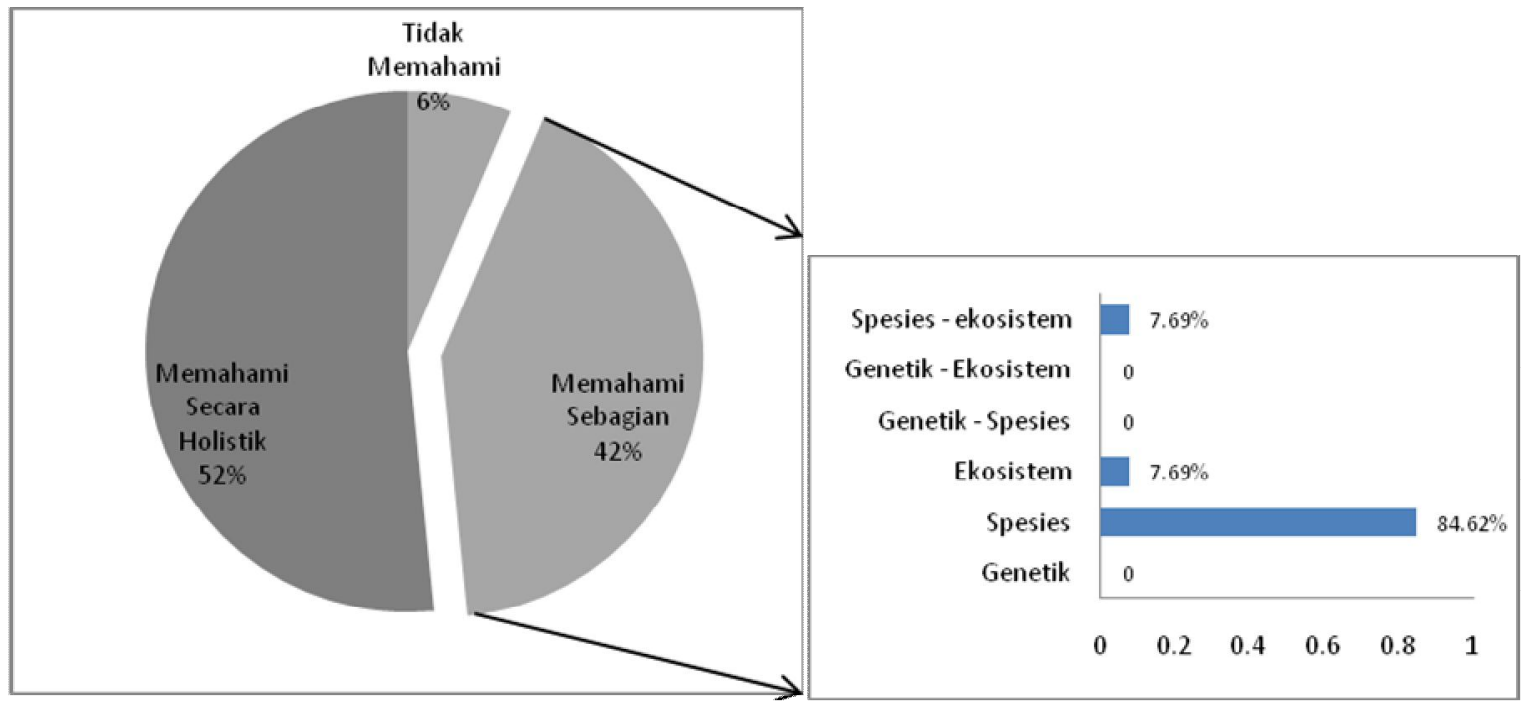

Gambar 1. Pemahaman Guru tentang Biodiversitas di Kabupaten/Kota Serang
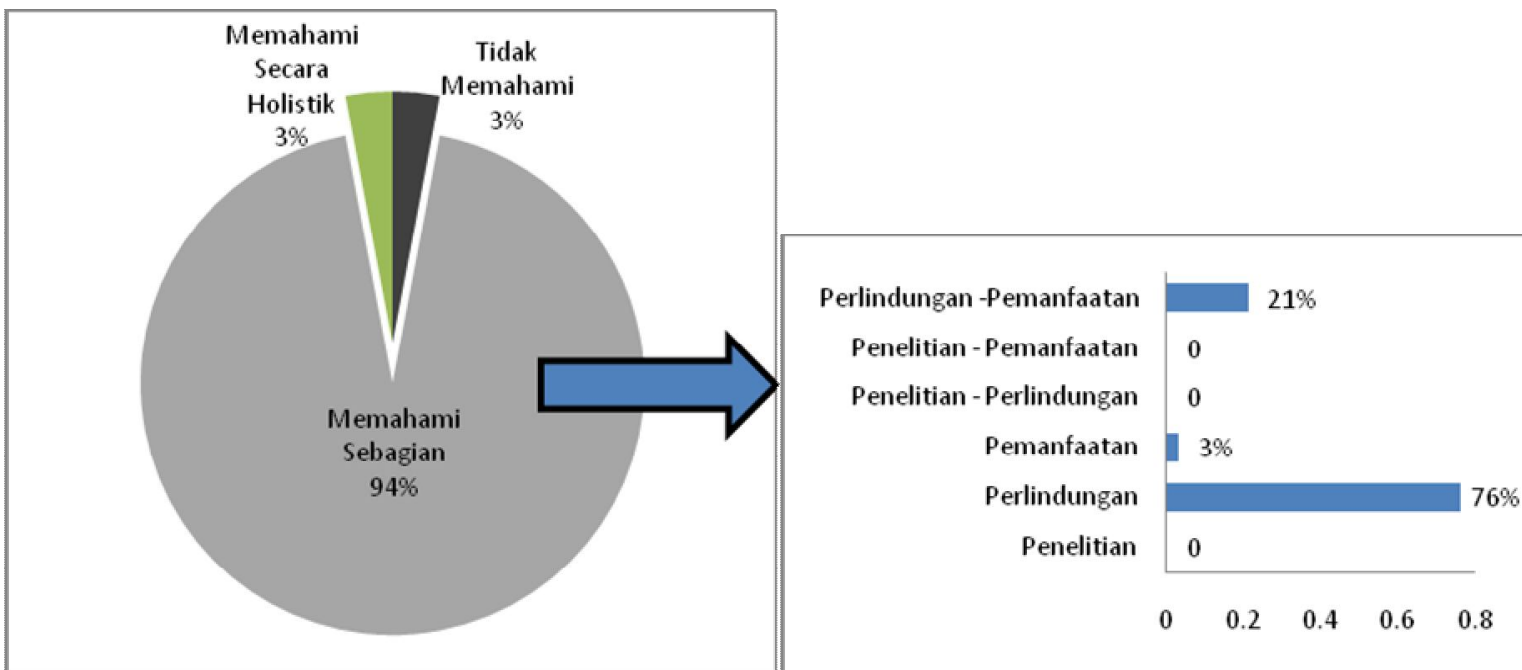

Gambar 2. Pemahaman Guru tentang Konsep Konservasi di KabupatenKota Serang

Gambar 2 juga menunjukkan bahwa guru di Kab./Kota Serang Banten sebagian besar (94\%) belum memahami makna konservasi secara holistik dan bahkan ada 3\% yang tidak memahami sama sekali makna konservasi. Guru yang belum memahami makna konservasi secara holistik tersebut sebagian besar (76\%) memaknai konsep konservasi sama dengan perlindungan saja, 3\% memaknai sama dengan pemanfaatan saja dan tidak ada $(0 \%)$ yang memaknainya sama dengan penelitian. Sebagian kecil (21\%) memaknai konservasi sama dengan kombinasi antara perlindungan-pemanfaatan dan tidak ada $(0 \%)$ yang memaknai konservasi sama dengan penelitian-pemanfaat- an dan penelitian-perlindungan. Data tersebut dapat disimpulkan bahwa guru biologi di Kab./ Kota Serang sebagian besar masih miskonsepsi tentang makna konservasi. Mereka memaknai konservasi dengan perlindungan saja, yang seharusnya mencakup tiga hal yaitu perlindungan, penelitian dan pemanfaatan. Hal inilah yang menyebabkan konservasi masih gagal. Oleh sebab itu, Rifai (2004) menyarankan perlunya mengubah mind set pendekatan dalam upaya konservasi dengan mengedepankan pemanfaatan secara lestari.

Rendahnya pemahaman konsep biodiversitas dan konservasinya tidak hanya terjadi di Indonesia. Summers $d k k$ (2005) menemukan 
miskonsepsi dan tidak lengkapnya pemahaman guru-guru sekolah dasar (SD) dan sekolah menengah pertama (SMP) tentang biodiversitas dan konservasinya terkait dengan empat isu lingkungan (biodiversity, carbon cycle, ozone dan global warming) di Inggris. Dikmenli (2010) menemukan masih dangkal dan terbatasnya kerangka konseptual mahasiswa calon guru biologi tentang biodiversitas di Turki. Penelitian ini memberikan dasar empiris untuk memberi saran yang berkaitan dengan content dan pedagogy tentang pembelajaran biodiversitas dan konservasinya.

Guru seharusnya dituntut untuk selalu menjaga profesionalismenya. Guru harus mampu menguasai materi dan mampu mengajarkannya dengan benar. Guru-guru Biologi di Kab./ Kota Serang sebagian besar (87\%) beranggapan bahwa materi konservasi biodiversitas mudah dipahami dibandingkan dengan materi IPA lainnya (Gambar 3). Padahal jika dilihat dari pemahaman mereka tentang konservasi dan biodiversitas, sebagian besar masih belum memahaminya secara holistik.

Kelemahan guru dalam menguasai konsep konservasi biodiversitas secara holistik dan up to date adalah jarangnya mereka ikut pelatihan yang berhubungan dengan konservasi biodiversitas. Gambar 4 menunjukkan bahwa bekal guru dalam menguasai konsep konservasi biodiversitas diperoleh sebagian besar $(81 \%)$ pada saat di sekolah menengah dan $58 \%$ pada saat kuliah. Hal ini dapat diartikan bahwa selama menjadi guru hampir sebagian besar mereka tidak mengupdate pengetahuannya. Pengetahuan konsep konservasi biodiversitas hanya $6 \%$ saja yang diperoleh pada saat mereka mengikuti pelatihan. Selebihnya mereka berusaha sendiri untuk mengupdate isu-isu konservasi biodiversitas melalui melalui media on-line (internet) 42\%, media elektronik $23 \%$ dan media cetak $23 \%$. Isu-isu konservasi biodiversitas yang terus berkembang pesat pada saat ini perlu dibekalkan kepada guru-guru. Oleh sebab itu, diperlukan pelatihan-pelatitan melaui Continuing Professional Development (CPD) sehingga pemahaman mereka tentang biodiversitas dan konservasi dapat bertambah dan sesuai dengan perkembangan jaman.

Gambar 4 juga menunjukkan bahwa peran teman (6\%), keluarga (0\%), organisasi lingkungan $(0 \%)$ dan kantor pemerintah $(0 \%)$ sangat kecil dan bahkan tidak ada dalam memberikan informasi isu-isu konservasi biodiversitas kepada guru. Hal ini serupa dengan hasil penelitian Lindemann-Matthies $d k k$ (2011) yang mendapatkan hasil bahwa keluarga, teman dan organisasi lingkungan kurang dari 10\% menjadi sumber informasi terkait dengan konservasi biodiversitas bagi calon guru di empat negara eropa yaitu Jerman, Inggris, Cyprus dan Swedia. Sumber informasi yang utama dalam mengupdate isu-isu konservasi biodiversitas bagi calon guru di empat negara eropa tersebut diperoleh pada saat perkuliahan. Hal ini dapat terjadi karena memang anggota masyarakat sebagian besar tidak peduli dengan konservasi biodiversitas. Hal ini diperkuat dengan hasil penelitian Fischer dan Young (2007) bahwa pemahaman masyarakat tentang konservasi biodiversitas masih lemah, sehingga kepedulian mereka terhadap konservasi juga rendah.

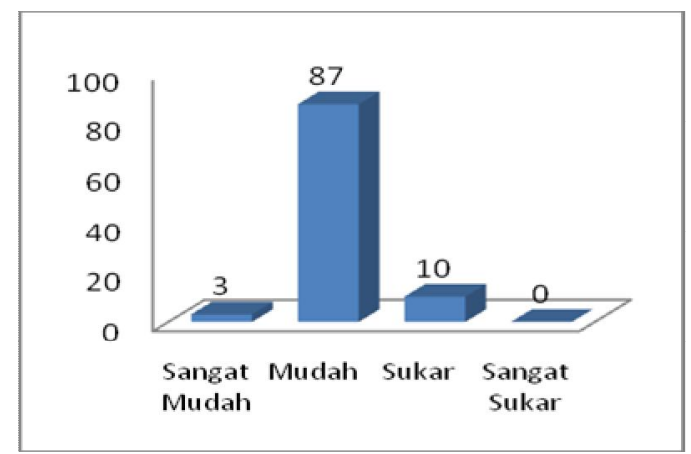

Gambar 3. Persepsi Guru Biologi di Kab/Kota Serang dalam Memahami Materi Konsep Konservasi Biodiversitas Dibandingkan dengan Materi IPA Lainnya (dalam \%) 


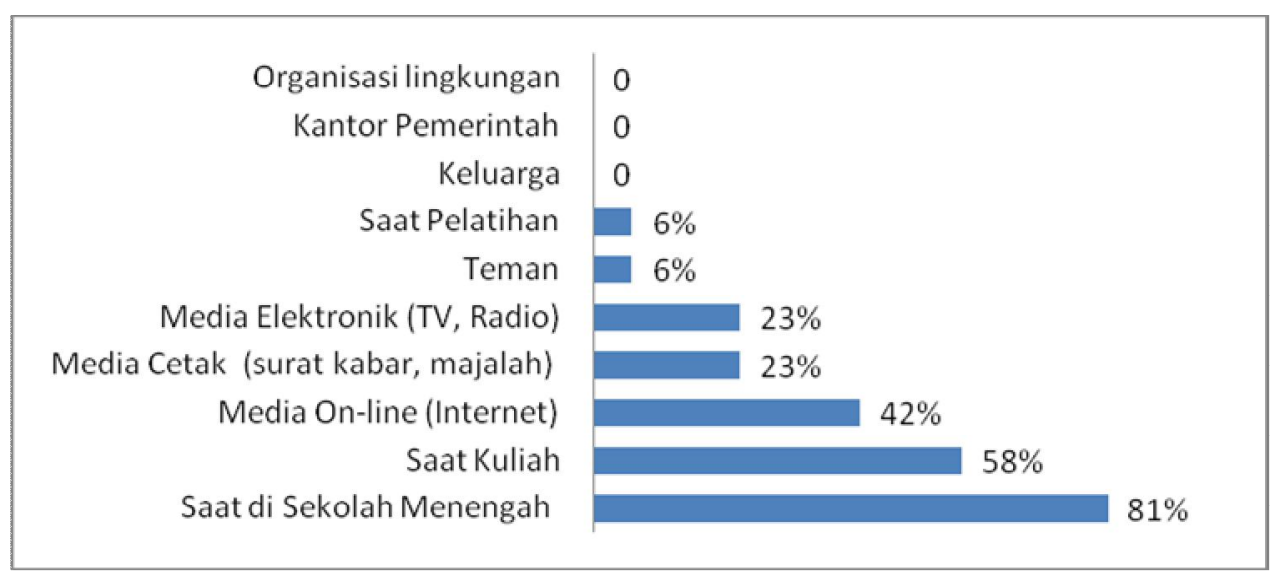

Gambar 4. Sumber Informasi Guru dalam Mendapatkan Konsep Konservasi Biodiversitas

\section{Kemampuan Guru dalam Merancang Pem- belajaran Konservasi Biodiversitas}

Di Indonesia pembelajaran konservasi biodiversitas telah masuk dalam pembelajaran biologi. Kurikulum Tingkat Satuan Pendidikan (KTSP) tahun 2006, telah menetapkan standar kompetensi dan kompetensi dasar untuk keanekaragaman hayati yang diajarkan pada Kelas X, Semester 2, sebagai tertera pada Tabel 1. Berdasarkan analisis SK dan KD yang tertera pada Tabel 1 tersebut dapat dirumuskan bahwa terdapat tiga tujuan pembelajaran konservasi biodiversitas di Sekolah. Ketiga tujuan tersebut adalah siswa mampu (1) mendeskripsikan konsep biodiversitas; (2) mengamati biodiversitas; dan (3) mengkomunikasikan isu-isu konservasi biodiversitas. Oleh sebab itu, model dan metode pembelajaran yang digunakan untuk dapat mencapai tiga tujuan tersebut harus melibatkan siswa secara aktif.

Hasil penelitian menunjukkan bahwa sebagian besar guru-guru biologi di Kabupaten/ Kota Serang belum mampu merancang pembelajaran konservasi dengan benar, walaupun sudah ada guru yang menerapkan model/ metode yang melibatkan siswa secara aktif seperti metode pengamatan atau observasi (58\%), diskusi $45 \%$, tanya jawab $16 \%$, penggunaan media word square dan charta $(6 \%)$, picture and picture $(6 \%)$, student teams achievement divi- sions (STAD) (3\%), reciprocal teaching 3\%, dan jigsaw 3\% (Gambar 5).

Model-model ini walaupun telah melibatkan siswa secara aktif, namun tiga tujuan pembelajaran konservasi belum tercapai. Modelmodel tersebut baru mewujudkan aspek pengamatan dan penguasaan konsep, namun belum mewujudkan aspek mengkomunikasikan konservasi biodiversitas. Gambar 5 menunjukkan bahwa model sains teknologi masyarakat (STM), presentasi kelompok, penugasan, pembelajaran berbasis projek dan masalah, group investigasi serta inquiri hampir tidak pernah dilakukan oleh guru-guru di Kab./Kota Serang. Padahal, model-model tersebut dapat mewujudkan tiga tujuan pembelajaran konservasi biodiversitas seperti yang tertera pada SK dan KD. Model pembelajaran berbasis projek misalnya, selain siswa harus menguasai konsep melalui pengamatan di sekitar lingkungannya, mereka juga harus mempresentasikan hasil temuannya berupa produk. Model pembelajaran berbasis masalah dan group investigasi juga menuntut siswa mampu menguasai konsep, mengamati biodiversitas di sekelilingnya dan menyampaikannya dalam bentuk laporan dan presentasi secara lisan (Sharan, 2012:160). Seorang guru yang profesional harus mampu merencanakan pembelajaran sesuai dengan SK dan KD yang telah ditetapkan (Uno, 2007:70). 
Tabel 1. Standar Kompetensi dan Kompetensi Dasar Pembelajaran Konservasi Biodiversitas pada KTSP

\begin{tabular}{|c|c|c|}
\hline $\begin{array}{c}\text { Standar } \\
\text { Kompetensi (SK) }\end{array}$ & Kompetensi Dasar (KD) & Konsep Esensial \\
\hline $\begin{array}{l}\text { 3. } \text { Memahami } \\
\text { manfaat } \\
\text { keanekaragaman } \\
\text { hayati }\end{array}$ & 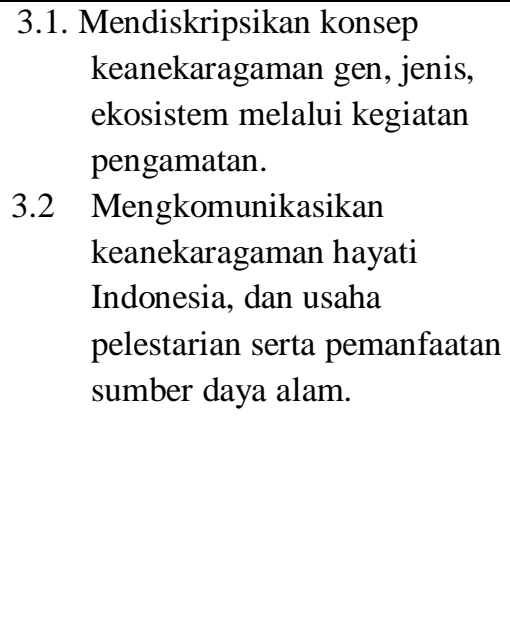 & $\begin{array}{l}\text { 1. Konsep keseragaman dan keberagaman dari } \\
\text { makhluk hidup } \\
\text { 2. Ciri-ciri keanekaragaman hayati pada } \\
\text { tingkat gen, jenis dan ekosistem } \\
\text { 1. Keanekaragaman hayati di Indonesia } \\
\text { berdasarkan keanekaragaman jenis, } \\
\text { ekosistem dan karakteristik wilayahnya } \\
\text { 2. Keunikan biodiversitas Indonesia } \\
\text { berdasarkan penyebarannya } \\
\text { 3. Tumbuhan dan hewan khas Indonesia } \\
\text { 4. Kegiatan manusia yang mempengaruhi } \\
\text { biodiversitas } \\
\text { 5. Upaya-upaya pelestarian biodiversitas di } \\
\text { Indonesia }\end{array}$ \\
\hline
\end{tabular}

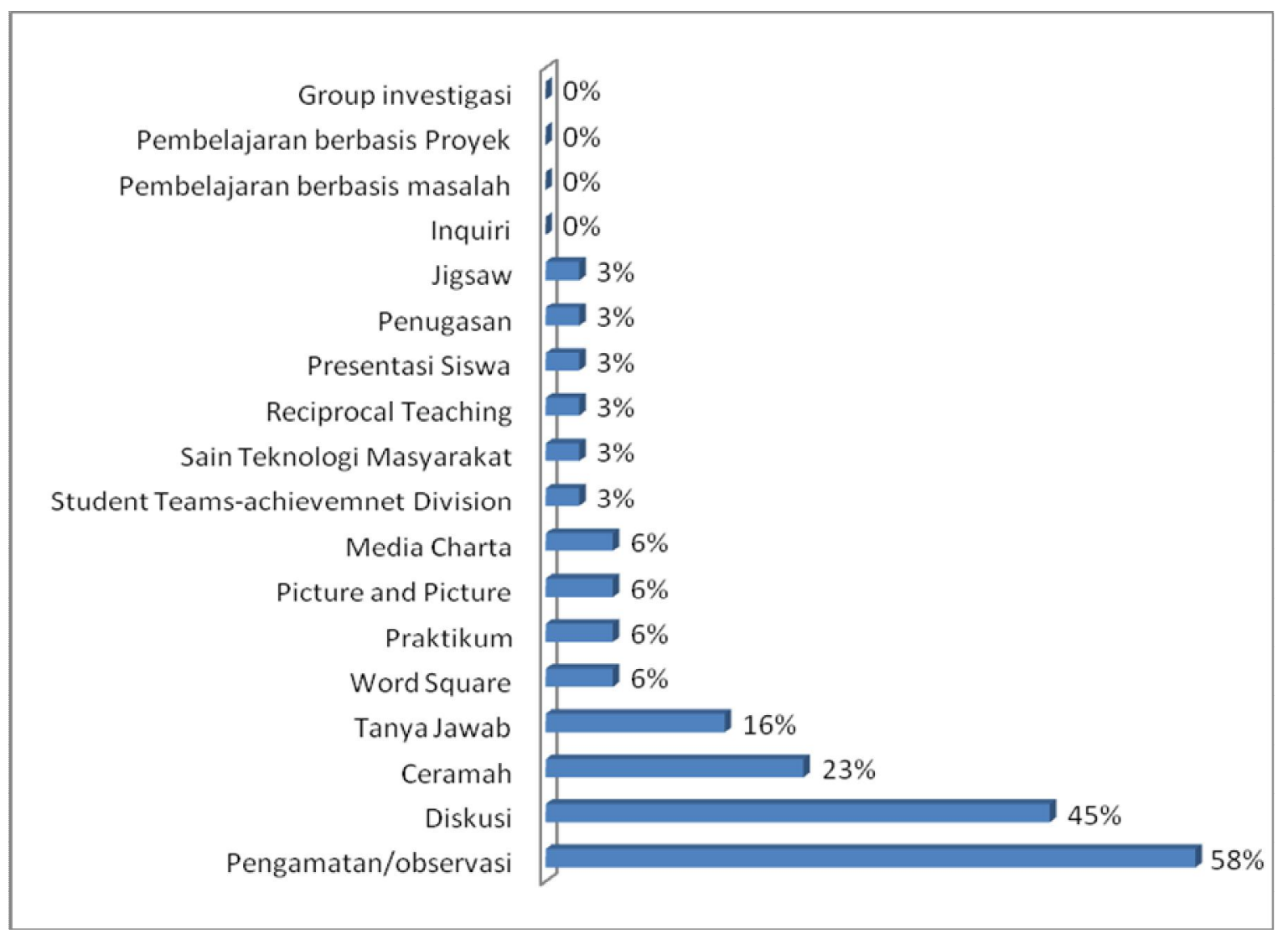

\section{Gambar 5. Model/Metode Guru dalam Mengajarkan Konservasi Biodiversitas di SMA/MA di Kab/Kota Serang}

Tiga tujuan pembelajaran konservasi biodiversitas hasil analisis SK dan KD dari Tabel 1 , yaitu siswa mampu menguasai konsep, mengamati dan mengkomunikasikan isu-isu konservasi biodiversitas tersebut dapat dikatakan se- bagai literasi biodiversitas. Erdogan (2009) menegaskan bahwa tujuan akhir pembelajaran konservasi biodiversitas adalah meningkatkan literasi biodiversitas siswa. Literasi biodiveritas dapat diartikan sebagai kemampuan seseorang 
untuk memahami biodiversitas, mengkomunikasikan biodiversitas (lisan dan tulisan), serta menerapkan pengetahuan konservasi biodiversitas untuk memecahkan masalah-masalah biodiversitas, sehingga memiliki sikap dan kepekaan yang tinggi terhadap diri dan lingkungannya dalam mengambil keputusan berdasarkan pertimbangan-pertimbangan ilmiah.

Oleh sebab itu, pelaksanaan pembelajaran konservasi biodiversitas seharusnya mencakup tiga dimensi, yaitu dimensi konten, proses, dan sikap literasi biodiversitas. Dimensi konten literasi biodiversitas merujuk pada penguasaan konsep-konsep kunci dari biodiversitas untuk memahami fenomena alam dan perubahan yang terjadi pada alam akibat aktivitas manusia. Dimensi proses literasi biodiversitas, membekali siswa mampu berpartisipasi dalam masyarakat. Siswa mencari, menganalisis dan menafsirkan bukti-bukti, menggali pertanyaan, mengidentifikasi bukti, menarik kesimpulan, mengkomunikasikan kesimpulan dan menunjukkan pemahaman konsep ilmiah.

Dimensi sikap literasi biodiversitas merujuk pada isu-isu penting dalam kehidupan sehari-hari yang dapat meningkatkan kepedulian pribadi dan sosial terhadap permasalahan-permasalahan biodiversitas. Oleh sebab itu, modelmodel pembelajaran yang digunakan seharusnya melibatkan peserta didik secara aktif, seperti memadukan pembelajaran di kelas dan pembelajaran di lapangan (Ramadoss \& Moli, 2011). Rahman \& Spafford (2009) menyatakan bahwa pembelajaran konservasi biodiversitas lebih ditekankan untuk mengukur konstruksi psikologis, seperti sikap, persepsi dan faktorfaktor kepribadian lainnya dari pada pengetahuan semata.

\section{Implikasi terhadap Continuing Professional Development (CPD) bagi Guru Biologi}

Continuing Professional Development (CPD) adalah pola pembinaan guru-guru secara berkelanjutan agar mereka selalu mengikuti perkembangan ilmu pengetahuan dan bagaimana cara mengajarknnya (Rose dan Reynolds, 2012). Pola pembinaan ini diperlukan agar guru-guru tetap profesional. Pembinaan profesi- onal guru pada tingkat Pemerintah Daerah dilaksanaan oleh lembaga/organisasi yang dibentuk berdasarkan ketentuan Dinas Pendidikan Provinsi dan Dinas Pendidikan Kota/Kabupaten yakni Pengawas dan Musyawarah Guru Mata Pelajaran (MGMP). Beberapa bentuk kegiatannya adalah dengan mengikuti diskusi yang berkaitan dengan permasalahan-permasalahan pembelajaran di kelas, workshop dan pelatihanpelatihan yang berhubungan dengan perkembangan ilmu pengetahuan dan teknologi pembelajaran terbaru.

Guru-guru di Kabupaten/Kota Serang rata-rata hanya $30 \%$ saja yang pernah mengikuti pelatihan yang berhubungan dengan konsep konservasi biodiversitas (Tabel 2). Hal ini disebabkan karena pelatihan yang dilaksanakan biasanya berdasarkan kebutuhan guru-guru di lapangan. Guru-guru di Kabupaten/Kota Serang menyatakan bahwa sebagian besar (87\%) beranggapan mudah memahami materi konservasi biodiversitas dan mudah mengajarkannya dibandingkan dengan materi IPA lainnya. Oleh sebab itu, pelatihan-pelatihan yang berkaitan dengan konservasi biodiversitas jarang dilaksanakan.

Tabel 2 juga menunjukkan bahwa selama menjadi guru, mereka $90 \%$ tidak pernah mengikuti pelatihan tentang penanganan isu konservasi biodiversitas yang up to date dalam mengajar. Misalnya tentang pelestarian badak bercula satu yang menjadi kebanggaan masyarakat Banten. Mereka juga sebagian besar $(90 \%)$ tidak pernah mendapatkan pelatihan tentang pengorganisasian dalam kegiatan outdoor, misalnya praktikum lapangan. Sebagian besar $(61 \%)$ tidak pernah mengikuti pelatihan tentang asesmen yang berhubungan dengan pembelajaran outdoor. Padahal pembelajaran konservasi biodiversitas seharusnya dilaksanakan di lapangan untuk mengenal secara langsung objek yang dipelajarinya. Pembelajaran outdoor, seperti field trips, dapat meningkatkan penguasaan konsep, keterampilan proses dan sikap siswa terhadap lingkungan sekitar (Rahman \& Spafford, 2009), serta dapat meningkatkan kompetensi sosial (Shakil, $d k k$. 2011). Asesmen untuk pembelajaran konservasi biodiversitas seharusnya juga 
beragam, mulai dari penguasaan konsep, serta lebih ditekankan pada mengukur konstruksi psikologis, seperti sikap, persepsi dan faktorfaktor kepribadian lainnya sesuai saran Rahman \& Spafford (2009). Oleh sebab itu, apabila guru-guru memahami pengorganisasian kegiatan outdoor dan asesmennya diharapkan literasi biodiveritas siswa dapat meningkat yang menjadi tujuan pembelajaran konservasi biodiveritas.

Tabel 2 juga menunjukkan bahwa selama menjadi guru, sebagian besar $(77 \%)$ tidak pernah mendapatkan pelatihan tentang philosofi pendidikan lingkungan, $65 \%$ tidak pernah mendapatkan pelatihan tentang permasalahan lingkungan global, dan $74 \%$ permasalahan lingkungan lokal serta $77 \%$ tidak pernah mendapatkan pelatihan tentang kearifan lokal yang terkait dengan konservasi biodiversitas. Padahal untuk mengajarkan konservasi biodiversitas dibutuhkan pendekatan pembelajaran berbasis budaya sesuai dengan rekomendasi Agenda 21. Sebenarnya, pendidikan berbasis budaya lokal ini dapat lebih meningkatkan perlindungan terhadap biodiversitas. Glasson $d k k$ (2010) telah melakukan penelitian untuk menggali potensi kearifan lokal di Malawi (Afrika) yang dapat digunakan untuk pembelajaran di sekolah. Pengetahuan-pengetahuan lokal tersebut pada prinsipnya sama dengan pengetahuan modern, sehingga prinsip-prinsip pengetahuan lokal dalam kehidupan alami dapat diadopsi untuk pembelajaran modern. Penelitian yang telah dilakukan Djulia (2005) juga menyimpulkan bahwa konsep-konsep sains masyarakat dapat mengatasi keterbatasan konteks dalam pembelajaran di sekolah. Penelitian ini semakin membuka wawasan guru akan pentingnya mendekatkan pengetahuan sains di sekolah dalam konteks budaya di tempat siswa berada dan belajar. Penelitian Snaddon $d k k$ (2008) menunjukkan bahwa persepsi siswa terhadap biodiversitas sangat dipengaruhi oleh apa yang sering dilihat dan didengar di sekitar lingkungan tempat mereka berada. Hal ini juga diperkuat dengan penelitian Hellden \& Hellden (2008), bahwa siswa mempunyai kemampuan yang lebih baik untuk mengenali dan mengidentifikasi tumbuhan dan hewan dengan mengaitkan pada pengalaman nyata sehari-hari. Pengalaman bersama keluarga merupakan pengalaman yang sangat penting dalam kemampuan mengidentifikasi biodiversitas. Hal ini dapat diartikan bahwa pembelajaran yang berbasis pengalaman sehari-hari dapat meningkatkan pemahaman siswa terhadap biodiversitas. Oleh sebab itu, guru-guru harus dibekali philosofi dan keterampilan menggali isu-isu lokal dan kearifan lokal dalam pembelajaran konservasi biodiversitas.

\section{Saran Kebijakan}

Penguasaan konsep konservasi biodiversitas guru-guru di Kab./Kota di Serang masih sangat kurang, hanya 3\% saja yang memahami konsep konservasi secara holistik. Sebanyak 76\% guru memaknai konservasi identik dengan perlindungan, yang artinya spesies flora dan fauna harus dilindungi dan tidak boleh dimanfaatkan. Pandangan seperti ini adalah paradigma yang salah. Makna konservasi selain mengandung unsur perlindungan, juga pemanfaatan secara lestari. Rifai (2004) menegaskan bahwa konsep konservasi adalah pemanfaatan sumber daya alam secara lestari. Setiap orang akan mengkonservasi flora dan fauna, berserta ekosistemnya dengan sendirinya kalau mereka tahu manfaatnya. Sebagai contoh, masyarakat Kasepuhan Banten Kidul yang masih mempunyai lebih dari 40 varietas padi lokal. Padi-padi tersebut akan terus dikonservasi walaupun tidak ada peraturan yang menganjurkannya karena mereka tahu manfaatnya.

Permasalan lainnya adalah guru-guru dalam mengajarkan konservasi biodiversitas masih banyak yang menggunakan metode konvensional. Model pembelajaran yang tepat untuk mengajarkan biodiversitas adalah dengan metode yang ikut melibatkan siswa dalam pembelajaran, misalnya yang disarankan oleh Dikmenli (2010), yaitu pembelajaran kooperatif, pembelajaran berbasis proyek dan kegiatan alam terbuka. Selain metode pembelajaran, konteks dalam belajar juga harus dikaitkan dengan kehidupan sehari-hari mahasiswa. Menurut teori belajar bermakna dari Ausubel, faktor yang paling penting yang mempengaruhi belajar adalah apa 
Tabel 2. Pelatihan yang Diikuti Selama Menjadi Guru di Kabupaten/Kota Serang Terkait dengan Pembelajaran Konservasi Biodiversitas

\begin{tabular}{lcc}
\hline Selama menjadi guru pelatihan yang pernah diikuti : & Ya (\%) & Tidak (\%) \\
\hline Penanganan isu konservasi biodiversitas yang up to date dalam mengajar & 10 & 90 \\
Pengorganisasian dalam kegiatan outdoor (praktikum lapangan) & 10 & 90 \\
Teknik pengembangan penilaian (asesmen) untuk pembelajaran outdoor & 39 & 61 \\
Model-model pembelajaran dalam pendidikan lingkungan (permainan dll) & 74 & 26 \\
Philosofi tentang pendidikan lingkungan & 23 & 77 \\
Permasalahan lingkungan global & 35 & 65 \\
Permasalahan lingkungan lokal & 26 & 74 \\
Kearifan lokal yang terkait dengan konservasi biodiversitas & 23 & 77 \\
Rerata keikutsertaan dalam mengikuti pelatihan & 30 & 70 \\
\hline
\end{tabular}

yang telah diketahui siswa (Dahar, 2011:95). Oleh sebab itu, agar terjadi belajar bermakna, konsep baru atau informasi baru harus dikaitkan dengan konsep-konsep yang ada dalam struktur kognitif siswa. Oleh sebab itu, materi yang dikemas untuk mengajarkan biodiversitas sebaiknya berasal dari pengalaman sehari-hari mahasiswa, sehingga mereka akan lebih paham terhadap materi yang diajarkan.

Dari analisis berdasarkan temuan di lapangan tersebut dapat disarankan bahwa Continuing Professional Development harus ditingkatkan melalui kegiatan pelatihan-pelatihan untuk memperbaharui guru dalam mengajarkan konservasi biodiversitas. Pelatihan yang dikembangkan harus dapat meningkatkan pedagogical-content knowledge (PCK) guru, yaitu pengetahuan guru berkaitan dengan materi pembelajaran, urutan materi pembelajaran, contohcontoh yang terkait dan metode pembelajaran yang efektif digunakan serta keterkaitannya dengan konsep lain dari materi yang sedang diajarkan. Materi pelatihan juga mencakup pendekatan kehidupan mereka sehari-hari dan memasukkan contoh-contoh kearifan lokal tentang biodiversitas untuk meningkatkan konten pembelajaran konservasi biodiversitas.

Selain itu, bagaimana mengemas konten untuk dapat diajarkan ke siswa juga perlu dilatih. Hal ini diharapkan siswa yang diajar akan mampu menghargai dan peduli terhadap lingkungan. Pelatihan juga mencakup metodemetode pembelajaran konservasi biodiversitas yang tepat, seperti metode yang dapat mengaktifkan mahasiswa belajar, sehingga kegiatan pembelajaran tersebut dapat mendorong mahasiswa untuk membentuk hubungan emosional dengan alam dan meningkatkan kepedulian mereka terhadap lingkungan hidup.

Peran Pemerintah Daerah melalui Dinas Pendidikan Provinsi dan Dinas Pendidikan Kota/Kabupaten sangat diperlukan dalam mendukung kinerja Musyawarah Guru Mata Pelajaran (MGMP). MGMP sangat berperan dalam menjalankan Continuing Professional Development (CPD) guru-guru melalui pelatihan-pelatihan guna meningkatkan kompetensi, pengetahuan, dan wawasannya.

\section{PENUTUP}

Pemahaman guru biologi di Kota/Kab. Serang tentang konsep konservasi biodiversitas masih rendah, namun mereka menganggap bahwa materi tersebut mudah dipahami dibandingkan dengan materi IPA lainnya. Kemampuan mereka dalam merancang pembelajaran konservasi biodiversitas juga masih rendah. Pembelajaran konservasi biodiversitas seharusnya diajarkan dengan pendekatan siswa aktif dengan materi kontektual. Mereka juga jarang mengikuti pelatihan yang berhubungan dengan konservasi biodiversitas, karena pelatihan yang berhubungan dengan materi tersebut jarang dilaksanakan. Oleh sebab itu, diperlukan pelatihanpelatihan yang berhubungan dengan konservasi biodiversitas, baik menyangkut konsep, metode 
dan model pembelajaran, maupun asesmennya, sehingga kemampuan guru dapat meningkat.

\section{UCAPAN TERIMAKASIH}

Penelitian ini merupakan bagian dari penelitian Disertasi Doktor, ucapan terimakasih penulis ucapkan kepada Prof. Dr. Mien A Rifai, dari LIPI Bogor yang telah bersedia memberikan masukan dan motivasinya.

\section{DAFTAR PUSTAKA}

Campbell, N.A., Reece, J.B., dan Mitchell, L.G. 2008. Biology. San Fransisco: Pearson Benjamin Cummings.

Dahar, R. W. 2011. Teori-Teori Belajar. Jakarta: Penerbit Erlangga.

Dikmenli, M. 2010. "Biology Student Teachers Conceptual Frameworks Regarding Biodiversity". Education 130 (3), hlm. 479 -489 .

Djulia, E. 2005. Peran Budaya Lokal dalam Pembentukan Sains (Studi Naturalistik Sains Siswa Kalompok Budaya Sunda tentang Fotosintesis dan Respirasi Tumbuhan dalam Konteks Sekolah dan Lingkungan Pertanian. Disertasi Doktor pada PPS UPI Bandung: Tidak Diterbitkan.

Erdogan, M. 2009. "Components Of Environmental Literacy in Elementary Science Education Curriculum in Bulgaria And Turkey". Eurasia Journal of Mathematics, Science and Teknology Education. 5(1).hlm 15-26.

Fischer, A., dan Young, J.C. 2007 "Understanding Mental Constructs of Biodiversity: Implications for Biodiversity Management and Conservation". Biological Conservation. 136, hlm. $271-282$.

Glasson, G.E., Mhango, N., Priri, A., \& Lanier, M. 2010. "Sustainablility Science Education in Africa: Negotiating Indigenous Ways of Living With Nature in The Thitrd Space". Innternational Journal of
Science Education. 32 (1), hlm. 125 141.

Hagenbuch, B.E., Bynum, N., Sterling, E., Bower, A.H., Cigliano, J.A., Abraham, B.J., Engels, C., Mull, J.F., Pierce, J.D., Zjhra, M.L., Rhode, J.M., Ketcham, S.R., dan Mayer, M. 2009. "Evaluating a Multi-Component Assessment Framework for Biodiversity". Education Teaching Issues and Experiments in Ecology. 6, hlm. 1-18.

Helldén, G. dan Helldén, S. 2008. "Students' Early Experiences of Biodiversity and Education for a Sustainable Future". Nordina 4 (2), hlm.123-130.

Indrawan, M., Primack, R.B. dan Supriatna, J. 2007. Biologi Konservasi. Jakarta: Yayasan Obor.

Lindemann-Matthies, P., Constantinou, C., Lehnert, H., Nagel, U., Raper, G., dan Kadji-Beltran, C. 2011. "Confidence and Perceived Competence of Preservice Teacher to Implement Biodiversity Education in Primary Schools- Four Comparative Case Studies From Europe". International Journal of Science Education. iFirst Article. hlm. 1-27.

Lude, A. 2010. The Spirit of Teaching ESDBiodiversity in Education Project. dalam Ulbrich, K (ed). Biodiversity in Education for Sustainable Development Reflection on school - Research cooperation. Sofia-Moscow: Pensoft Publishers.

Maclaurin, J., dan Sterelny, K. 2008. What Is Biodiversity? Chicago: The University of Chicago Press.

Rahman, T. \& Spafford, H. 2009. Value of field trips for student learning in the biological sciences. In Teaching and learning for global graduates. Proceedings of the 18th Annual Teaching Learning Forum, 
29-30 January 2009. Perth: Curtin University of Technology

Ramados, A. dan Moli, G.P. 2011. "Biodiversity Conservation Through Environmental Education for Sustainable Development - A Case Study From Puducherry, India". International Electronic Journal of Environmental Education, 1 (2), hlm.97-111.

Rifai, M.A. 2004. "Keanekaragaman Hayati Indonesia: Potensi Tak Tergali, Peluang Tak Termanfaatkan, dan Tantangan Tak Terjawab - Bagaimana Memperbaiki Semua Keterpurukan Ini?" Lingkungan dan Pembanguanan 24 (1), hlm.1-16

Shakil, A.F., Faizi, W.N., Hafeez, S. 2011. "The Need And Importance Of Field Trips At Higher Level In Karachi, Pakistan". International Journal Of Academic Research In Business And Social Sciences, 2 (1) : hlm. $1-16$.

Sharan, S. 2012. The Handbook Of Cooperative Learning. Yogyakarta: Familia.
Snaddon, J.L., Turner, E.C., \& Foster, W.A. 2008. "Children's Perceptions of Rainforest Biodiversity: Which Animals Have the Lion's Share of Environmental Awareness?" PLoS ONE. 3 (7), hlm. 1-5.

Summers, M., Childs, A., dan Corney, G. 2005. "Education for Sustainable Development in Initial Teacher Training: Issues for Interdisciplinary Collaboration". Environmental Education Research. 11, hlm 623-647.

Supriatna, J. 2004. "Penelitian Strategis dalam Pengembangan Konservasi Keanekaragaman Hayati di Indonesia”. Lingkungan dan Pembanguanan 24 (1), hlm. 30-49.

Uno, H. 2007. Profesi Pendidikan, Problema, Solusi dan Reformasi Pendidikan di Indonesia. Jakarta: Bumi aksara.

Western, D. dan Pearl, M.C 1989. Conservation for the Twenty-first Century. New York: Oxford University Press. 